\title{
Editorial: Ethnography and dance research
}

\section{Karen Barbour \\ The University of Waikato}

This first volume of articles in Dance Research Aotearoa focuses on the work of dance researchers who have deliberately engaged in contemporary forms of ethnographic research. Most of the authors in this volume participated in the international Contemporary Ethnography Across the Disciplines Hui/Conferences (CEAD), hosted by The University of Waikato in New Zealand in 2010 and 2012. These articles reflect the fruitful engagement of dance researchers with this wide audience of ethnographers from many disciplines. Engaging with issues of reflexivity, pedagogy, cultural responsiveness, performance, individual and group identities, nationalism, ethics and representation, their discussions reveal valuable insights about socio-cultural and political contexts generally, as well as knowledge that relates to dance specifically.

Dance researchers appreciate that embodied participation is integral, whether in choreographic and performance research, teaching dance in formal education or community contexts, developing creative writing methods to represent lived experience, or in other contexts in which dance researchers engage. Likewise, in ethnographic research a commitment to participation with research participants and communities is integral, in everyday life as well as in extraordinary practices. The articles in this volume reveal that the integration of ethnographic methods and dance practices has the potential to allow communities of dancers and researchers to work together in a range of relationships, and to share the voices of dance communities. These voices may then be woven together to engage critically and artistically with relevant wider communities, whether education students, educators, performers, policy makers or other researchers. Thus, the use of ethnographic methods offers much to dance researchers from the basis of a shared commitment to embodied participation of the researcher and research participants.

In dance ethnography, as in ethnography in general, researchers participate and observe, moving backwards and forwards between the specifics of personal, 
embodied, lived experience and cultural, political, social commentary. As Laurel Richardson states,

The ethnographic life is not separable from the self. Who we are and what we can be-what we can study, how we can write about that which we study-is tied to how a knowledge system disciplines itself and its members, its methods for claiming authority over both the subject matter and its members. Our task is to find the concrete practices through which we can construct ourselves as ethical subjects engaged in ethical ethnography-inspiring to read and to write. (Richardson, 2000, p. 16)

In a sense, ethnography itself offers dancers a 'concrete' research practice through which to anchor ethical dance research. Thus, engagement with ethnography offers much to dancers as an established discipline with an existing audience with whom dance researchers can speak. Further, ethnography offers understandings of subjectivity, reflexivity and ethics that are valuable for dance researchers who are engaging personally in practice and with communities every day.

Ethnographic dance research offers the opportunity to construct stories or snapshots of dancing lives, within which embodied ways of knowing are demonstrated. These stories or snapshots are created from participant observations and reflections, interviews, focus groups, choreographic processes, performances, journal writings by researchers and participants, innovative writing approaches, descriptions of scenes, images and more. Participating in both familiar and unknown dance contexts brings dancers face to face with issues of representation of self and others in research. Thus, ethnography offers dance researchers a context for challenging and expanding representational styles, drawing on the breadth of emerging, innovative methods such as autoethnography and performance ethnography (Barbour, 2011, in press; Davida, 2011; Denzin, 2003, 2006; Ellis, 2004; Madison, 2005, 2006, 2007; Richardson, 2000, 2005; Rinehart, Barbour \& Pope, in press).

Dance Research Aotearoa has a particular focus on dance in and by dance researchers working in Aotearoa and the South Pacific. While this first issue has a focus on dance ethnography, researchers engaging with varied qualitative, interpretive perspectives and research methods are invited to submit to subsequent issues. Researchers working with performative, pedagogical, feminist, Kaupapa Māori, indigenous, practice-based, ethnographic, Pasifika, critical, queer 
theory, cultural studies, phenomenological, postmodern and other qualitative research perspectives and methodologies are encouraged to submit. Authors may submit research articles, critical reflective essays and creative representations of research including narrative, autoethnographic, performative, poetic and imagebased submissions. A 'Looking Back' feature, incorporating a reprinted historic article with current responses, and book reviews may also be published regularly. While the journal focus is dance research in and by researchers working in Aotearoa and the South Pacific, submissions may also be made by international dance researchers. The Editor and/or any Special Issue Editor/s will advise on the suitability of the submission for the journal. Further information about submitting to the journal is available on the website http://www.dra.ac.nz

Ultimately, the aim of Dance Research Aotearoa is to provide a context for established and emerging dance researchers in the South Pacific region to publish in a peer-reviewed, internationally accessible online journal. As a collection of articles, the journal will also provide a much-needed local resource for tertiary undergraduate, graduate and doctoral students in dance.

The authors in this first issue of Dance Research Aotearoa share research experiences at home and abroad, engaging with 'others' and reflecting on 'self' as they write themselves between community events and festivals, performances and dance studios, school classrooms and universities. Their stories are inspiring and thought-provoking. Enjoy.

Many thanks are due to all those who have contributed to the establishment of this journal-authors, willing peer-reviewers, editorial board members, colleagues, family members, Professor Bronwen Cowie, Margaret Drummond, Sarah McAnallen and members of the Wilf Malcolm Institute of Educational Research (WMIER) at The University of Waikato, and colleagues from the Tertiary Dance Educators' Network New Zealand Aotearoa (TDENNZA). Special acknowledgements go to Raewyn Whyte, editor of the Dance News quarterly magazine (published 1981-1987), and Jan Bolwell, editor of the dance journal Tirairaka: Dance in New Zealand (published 2000-2004), for their inspiration to continue providing a context for publishing academic writing about dance in our parts of the world. Ngā mihi nui ki a koutou.

Karen Barbour

Editor 


\section{REFERENCES}

Barbour, K. N. (2011). Dancing across the page: Narrative and embodied ways of knowing. Bristol, UK: Intellect Books.

Barbour, K. N. (in press). Acts of representation: A labour of love. In R. Rinehart, K. N. Barbour \& C. Pope (Eds.), Ethnographic worldviews: Transformations and social justice. Dordrecht, The Netherlands: Springer.

Davida, D. (Ed.) (2011). Fields in motion: Ethnography in the worlds of dance. Waterloo, ON, Canada: Wilfrid Laurier University Press.

Denzin, N. K. (2003). Performance ethnography: Critical pedagogy and the politics of culture. Thousand Oaks, CA: Sage.

Denzin, N. K. (2006). The politics and ethics of performance pedagogy. In D. S. Madison \& J. Hamera (Eds.), The Sage handbook of performance studies (pp. 325-338). Thousand Oaks, CA: Sage.

Ellis, C. (2004). Ethnographic I: A methodological novel about autoethnography. Walnut Creek, CA: AltaMira Press.

Madison, D. S. (2005). Critical ethnography: Method, ethics, and performance. London, UK: Sage.

Madison, D. S. (2006). The dialogic performative in critical ethnography. Text and Performance Quarterly, 26(4), 320-324.

Madison, D. S. (2007). Performing ethnography: The political economy of water. Performance Research, 12(3), 16-27.

Richardson, L. (2000). New writing practices in qualitative research. Sociology of Sport Journal, 17, 5-20.

Richardson, L. (2005). Writing: A method of inquiry. In N. K. Denzin \& Y. S. Lincoln (Eds.), The Sage handbook of qualitative research (2nd ed.), (pp. 959-978). Thousand Oaks, CA: Sage.

Rinehart, R., Barbour, K. N., \& Pope, C. (in press). Proem: Engaging contemporary ethnography across the disciplines. In R. Rinehart, K. N. Barbour \& C. Pope (Eds.), Ethnographic worldviews: Transformations and social justice. Dordrecht, The Netherlands: Springer. 